\title{
Pembelajaran Bahasa Indonesia dalam Kurikulum 2013 berbasis Teks yang Berorientasi pada Pendekatan Saintifik
}

\author{
Nur Mei Ningsih ${ }^{\mathbf{1}}$ \\ Program Studi Pendidikan Bahasa dan Sastra Indonesia \\ STKIP Muhammadiyah Kotabumi
}

\begin{abstract}
Abstrak
Learning in the educational system can not be separated from the development of science and technology. The development of education notes that the era of the XXI Century there was a great shift on learning. Fundamental changes to access to information, computing, automation, and communication impact on the learning model of the XXI Century that directs learners into the focus of learning. Learners are conditioned actively so that the learning center is centered on the student centered. In the curriculum 2013 Indonesian language learning in textbased schools or more focused on the text. Text-based learning involves a process by which teachers help students produce text and gradually reduce aid so that students are able to produce text independently. Through these texts besides being taught linguistics also integrated character education. Especially through scientific or scientific approach, the formation of characters will be easily realized. In a scientific approach, students are asked to observe, question, try, associate, and communicate / summarize the core of the material related to learning Indonesian.
\end{abstract}

Kata Kunci: Pembelajaran Bahasa Indonesia berbasis teks, pendekatan saintifik

\section{PENDAHULUAN}

Salah satu permasalahan pendidikan yang menjadi prioritas adalah masalah kualitas pendidikan, khususnya kualitas pembelajaran. Dari berbagai kondisi dan potensi yang ada, upaya yang dapat dilakukan untuk peningkatan kualitas pembelajaran di sekolah adalah mengembangkan pembelajaran yang berorientasi pada peserta didik dan memfasilitasi kebutuhan masyarakat akan pendidikan yang berkelanjutan.

Upaya peningkatan mutu pendidikan melalui perbaikan proses pembelajaran merupakan inovasi yang terus dilakukan. Salah satu inovasi tersebut adalah mengubah paradigma pembelajaran dari pembelajaran yang berpusat pada guru menjadi pembelajaran yang berpusat pada siswa. Pendekatan pembelajaran yang dilakukan di sekolah selama ini berpusat pada guru atau berbasis mengajar, artinya bahwa salam proses pembelajaran guru lebih banyak memberi materi yang berupa pengetahuan.

Pada kondisi sekarang ini pembelajaran tidak lagi bersifat konvensional yang lebih menekankan pada 
pengajarnya, tetapi diubah menjadi berpusat pada peserta didik atau berbasis belajar. Adapun ciri utama dalam pembelajaran berbasis belajar supayaterbangunnya kemandirian siswa untuk membangun pengetahuan dan ketrampilan di dalam dirinya sendiri dari berbagai variasi informasi melalui interaksi dalam pembelajaran di sekolah.

Pembelajaran dalam sistem pendidikan tidak dapat dipisahkan dari perkembangan ilmu pengetahuan dan teknologi. Perkembangan pendidikan mencatat bahwa era Abad XXI terdapat pergeseran yang sangat besar tentang pembelajaran. Perubahan yang mendasar terhadap akses informasi, komputasi, otomatisasi, dan komunikasi berdampak terhadap model pembelajaran Abad XXI yang mengarahkan pembelajar menjadi fokus dari pembelajaran. Pembelajar dikondisikan aktif sehingga pusat pembelajaran bertumpu kepada pembelajar atau peserta didik (student centered). Proses pembelajaran yang bertumpu pada peserta didik, harapanya supaya peserta didik bukan hanya mendapatkan pengetahuan saja, tetapi terampil juga dalam menerapkan apa yang sudah didapat melalui proses pembelajaran. Proses pembelajaran yang dilakukan tentu tidak terlepas dari kurikulum yang diacu, dalam hal ini kurikulum yang digunakan adalah kurikulum 2013.
Kurikulum 2013 untuk sekolah menengah atas mata pelajaran bahasa Indonesia, SKL dibagi menjadi tiga ranah yaitu, ranah sikap, ranah pengetahuan, dan ranah keterampilan. Isi ketiga ranah tersebut terlampir dalam Permendikbud Nomor 54 Tahun 2013.

Dalam kurikulum 2013 pembelajaran bahasa Indonesia di sekolah berbasis teks atau lebih difokuskan pada teks. Melalaui teks-teks tersebut selain diajarkan ilmu kebahasaan juga diintegrasikan pendidikan karakter. Melalui membaca teks peserta didik mampu memperbaiki sikap untuk lebih berkarakter. Terlebih melalui pendekatan saintifik atau ilmiah pembentukan karakter akan mudah terealisasikan. Dalam pendekatan saintifik, siswa diminta unntuk mengamati, menanya, mencoba, mengasosiasi, dan mengomunikasikan.

Kegiatan-kegiatan tersebut dilakukan dengan integrasi pembentukan sikap, misal mengamati dengan tanggung jawab, menanya dengan santun, mencoba dengan jujur, dan mengasosiasi dan mengomunikasikan dengan proaktif. Sikap baik tersebut akan terus ditanamkan dalam setiap pembelajaran sehingga ketika peserta didik sudah terbiasa dengan sikap baik kebiasaan itu akan menjadi sifat, ketika peserta didik yang menjadi generasi penerus sudah menjadi pribadi yang baik 
tentu saja akan mengembalikan identitas bangsa menjadi bangsa yang bermartabat.

Pembelajaran berbasis teks merupakan pembelajaran yang berorientasi pada kemampuan siswa untuk menyusun teks. Bagaimana peserta didik mampu mengonstruksi-kan pengetahuannya dan terampil menyusun serta mampu mengembangkan teks. Metode pembelajaran ini mendasarkan pada pemodelan teks dan analisis terhadap fitur-fitur secara eksplisit serta fokus pada hubungan antara teks dan konteks penggunaanya. Dalam proses pembelajaran ini mengarah pada peserta didik agar mampu memahami dan memproduksi teks baik secara lisan maupun secara tulisan dalam berbagai konteks.

\section{PEMBAHASAN}

\section{A. Pembelajaran Bahasa Indonesia}

\section{Berbasis Teks}

Pembelajaran adalah kegiatan yang dilakukan oleh pendidik dan peserta didik untuk mencapai kompetensi yang diharapkan. Dalam proses pembelajaran tentunya melibatkan dua unsur yang tidak terpisahkan yaitu antara pendidik (guru) dan peserta didik (siswa). Kompetensi yang akan dicapai dalam kegiatan pembelajaran mengacu pada standar kompetensi lulusan (SKL) berdasarkan jenjang masing-masing (Priyatni, 2014: 270).
Dalam kurikulum 2013 selain dilakukan pengembangan kompetensi juga ditanamkan pendidikan karakter. Kurikulum 2013 memuat empat kopetensi yakni religius, social, pengetahuan, dan keterampilan. Berdasarkan keempat kompetensi religius dan social, ini sudah mewakili pada pengembangan karakter pada diri sndiri. Nilai karakter tersebut dapat mengembangkan kepribadian peserta didik untuk menjadi lebih baik. Dengan harapan kompetensi lulusan tidak hanya menjadi pribadi yang cerdas tetapi juga menjadi pribadi yang baik. Pendidikan karakter diintegrasikan dalam setiap mata pelajaran, misalnya pada mata pelajaran bahasa Indonesia di sekolah menengah atas dengan mata pelajaran lain seperti agama PKn, sehingga pembelajaran menjadi holistic.

Kurikulum 2013 untuk mata pelajaran bahasa Indonesia menggunakan teks dalam sarana pembelajarannya. Oleh karena itu, dapat dinyatakan bahwa kurikulum 2013 untuk mata pelajaran bahasa Indonesia berbasis teks. Hal tersebut terlampir dalam Permendikbud Nomor 69 Tahun 2013. Pada jenjang SMA/MA dan SMK/MAK terdapat 15 jenis teks yaitu (1) teks anekdot, (2) teks eksposisi, (3) teks laporan hasil observasi, (4) teks prosedur kompleks, (5) teks negosiasi, (6) teks cerita pendek, (7) teks pantun, (8) teks cerita ulang, (9) teks 
eksplanasi komplek, (10) teks film/darma,

(11) teks cerita sejarah, (12) teks berita,

(13) teks iklan, (14) teks editorial/opini, dan (15) teks novel. Lima belas jenis teks inilah yang akan disampaikan dalam pembelajaran bahasa Indonesia di sekolah menengah atas. Adapun pengertian singkat dari kelima belas jenis teks ini adalah sebagai berikut,( Priyatni: 2014:66)

\section{a) Teks Anekdot}

Teks anekdot adalah jenis teks yang berisi peristiwa-peristiwa lucu, konyol, atau menjengkelkan sebagai akibat dari krisis yang ditanggapi dengan reaksi. Struktur teks anekdot adalah abstraksi orientasi krisis reaksi koda.

b) Teks Eksposisi

Teks eksposisi adalah jenis teks yang berisi pernyataan pendapat atau suatu usulan disertai argumentasi yang tepat atau kuat. Struktur dari teks eksposisi adalah pernyataan (tesis) argumentasi penegasan ulang pendapat.

c) Teks Laporan Hasil Observasi

Teks laporan adalah teks yang berisi penjabaran umum mengenai sesuatu yang didasarkan pada hasil observasi. Struktur teks laporan adalah pernyataan umum/klasifikasi/anggota yang dilaporkan. d) Teks Prosedur Komleks

Teks prosedur kompleks adalah teks yang berisi langkah-langkah untuk melakukan sesuatu, dari setiap langkah-langkah itu tidak dapat diganti atau dihilangkan. Struktur teks prosedur komplek adalah tujuan langkah-langkah.

e) Teks Negosiasi

Teks negosiasi adalah teks yang berisi pemecahan persoalan dengan mencari penyelesaian diantara pihak-pihak yang yang memiliki perbedaan kepentingan. Struktur teks negosiasi adalah pembukaan, isi, dan penutup.

f) Teks Cerita Pendek

Teks cerita pendek tergolong kedalam gender sastra. Tek cerita pendek seperti narasi. Struktur teksnya seperti yang tercermin dalam unsur inrtinsik cerpen yaitu pada alur ceritanya.

g) Teks Pantun

Teks pantun juga tergolong gender sastra, pantun atau syair lama memiliki bentuk paragraf pertama berupa sampiran dan paragraf berikutnya adalah isi. Biasanya pantun juga bersajak AB, AB.

h) Teks Eksplanasi Komplek

Teks eksplanasi adalah jenis teks yang berisi penjelasan hubungan logis dari beberapa peristiwa. Pada 
teks eksplanasi, sebuah peristiwa muncul karena ada peristiwa lain sebelumnya dan peristiwa tersebut mengakibatkan peristiwa yang lain lagi sesudahnya. Srtuktur teks eksplanasi adalah pernyataan umum urutan alasan logis.

\section{i) Teks Film/Drama}

Teks film atau drama juga tergolong teks gender sastra. teks drama diungkapkan degan dialog antartokoh.

Melalui teks-teks tersebut selain di ajarkan ilmu kebahasaan juga ditanamkan pendidikan karakter. Pendidikan karakter yang dimaksud yaitu mengimplementasikanKI 1 danKI 2 kedalam setiap proses pembelajaran. KI 1 sebagai ranah sikap spiritual akan ditanamkan dengan mengsyukuri anugrah Tuhan akan keberadaan bahasa Indonesia dan menggunakannya untuk sarana berkomunikasi untuk mempersatukan bangsa. KI 2 sebagai ranah sikap sosial yaitu menanamkan sikap jujur, disiplin, tanggung jawab, dan santun dalam setiap kegiatan pembelajaran. Dalam pembelajaran berbasis teks guru mengenalkan teks dan tujuannya, serta fitur-fitur, membimbing siswa memproduksi teks melalui proses pemberian bantuan.

Pembelajaran berbasis teks melibatkan proses dimana guru membantu siswa dalam memproduksi teks dan secara bertahap mengurangi bantuan tersebut sampai siswa mampu memproduksi teks sendiri. Melalui teks yang diberikan kepada peserta didik, supaya peserta didik tersebut mampu memproduksi untuk menjadi lebih baik.

Emilia (2011:33) menyatakan bahwa teks merupakan satu kesatuan bahasa lengkap secara sosial dan kontekstual yang mungkin bisa dalam bentuk bahasa lisan maupun tulisan. Teks selalu dibuat dalam konteks. Kata konteks selalu mengacu pada elemen-elemen yang menyertai teks. Konteks memiliki peran yang sangat penting dalam penggunaan bahasa, karena apa yang ditulis atau yang dikatakan sangat tergantung pada topik, kapan dan dimana.

\section{B. Prinsip Pembelajaran Berbasis Teks}

Emilia (2011:21-22) menyatakan prinsip utama pembelajaran berbasis teks yaitu:

a) Menekankan pentingnya guru mengembangkan kesadaran siswa bahwa setiap teks merupakan kreasi unik dari seorang penulis yang unik juga dan bersifat relative.

b) Menganggap belajar bahasa sebagai aktivitas social yang meniscayakan kebergantungan antarsiswa dan masyarakat (teman, 
guru, orang tua) yang membantu dalam mencapai hasil belajar yang lebih baik.

c) Menekankan bahwa belajar akan berjalan lebih efektif jika guru menerangkan secara eksplisit kemampuan yang diharapkan.

Kebijakan Nasional tentang Pembelajaran dalam Permendikbud No. 81A tahun 2013 Lampiran IV, Proses pembelajaran terdiri atas lima pengalaman belajar pokok yaitu:

a) mengamati;

b) menanya;

c) mengumpulkan informasi;

d) mengasosiasi; dan

e) mengkomunikasikan.

Kelima pembelajaran pokok tersebut dalam praktek di sekolah jenjang pendidikanMenengah dikenal dengan pendekatan saintifik..Kelima pengalaman di atas dapat dirinci dalam berbagai kegiatan belajar dalam tabel berikut:

\section{Keterkaitan antara Langkah Pembelajaran dengan Kegiatan Belajar dan Kompetensi Pembelajar}

\begin{tabular}{|l|l|l|}
\hline $\begin{array}{l}\text { Langkah } \\
\text { Pembelaj } \\
\text { aran }\end{array}$ & $\begin{array}{l}\text { Kegiatan } \\
\text { Belajar }\end{array}$ & $\begin{array}{l}\text { Kompete } \\
\text { nsi yang } \\
\text { Dikemba } \\
\text { ngkan }\end{array}$ \\
\hline $\begin{array}{l}\text { Mengamat } \\
\text { i }\end{array}$ & $\begin{array}{l}\text { Membaca, } \\
\text { mendengar, } \\
\text { menyimak, } \\
\text { melihat (tanpa }\end{array}$ & $\begin{array}{l}\text { Melatih } \\
\text { kesunggu } \\
\text { han, } \\
\text { ketelitian, }\end{array}$ \\
\hline
\end{tabular}

\begin{tabular}{|c|c|c|}
\hline $\begin{array}{l}\text { Langkah } \\
\text { Pembelaj } \\
\text { aran }\end{array}$ & $\begin{array}{l}\text { Kegiatan } \\
\text { Belajar }\end{array}$ & $\begin{array}{l}\text { Kompete } \\
\text { nsi yang } \\
\text { Dikemba } \\
\text { ngkan }\end{array}$ \\
\hline & $\begin{array}{l}\text { atau dengan } \\
\text { alat) }\end{array}$ & $\begin{array}{l}\text { mencari } \\
\text { informasi }\end{array}$ \\
\hline Menanya & $\begin{array}{l}\text { Mengajukan } \\
\text { pertanyaan } \\
\text { tentang } \\
\text { informasi yang } \\
\text { tidak dipahami } \\
\text { dari apa yang } \\
\text { diamati atau } \\
\text { pertanyaan } \\
\text { untuk } \\
\text { mendapatkan } \\
\text { informasi } \\
\text { tambahan } \\
\text { tentang apa yang } \\
\text { diamati } \\
\text { (dimulai dari } \\
\text { pertanyaan } \\
\text { faktual sampai } \\
\text { ke pertanyaan } \\
\text { yang bersifat } \\
\text { hipotetik) }\end{array}$ & $\begin{array}{l}\text { Mengemb } \\
\text { angkan } \\
\text { kreativitas } \\
\text { ingin rasa } \\
\text { tahu, } \\
\text { kemampu } \\
\text { an } \\
\text { merumusk } \\
\text { an } \\
\text { pertanyaa } \\
\text { n untuk } \\
\text { membentu } \\
\mathrm{k} \text { pikiran } \\
\text { kritis yang } \\
\text { perlu } \\
\text { untuk } \\
\text { hidup } \\
\text { cerdas dan } \\
\text { belajar } \\
\text { sepanjang } \\
\text { hayat. }\end{array}$ \\
\hline $\begin{array}{l}\text { Mengump } \\
\text { ulkan } \\
\text { informasi/ } \\
\text { eksperime } \\
\text { n }\end{array}$ & 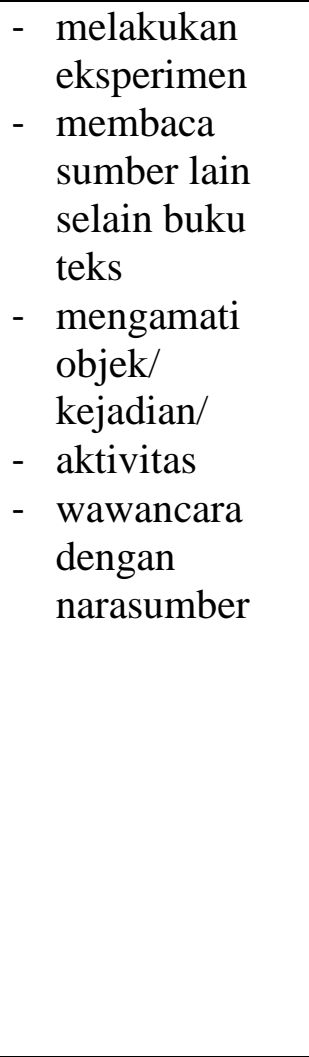 & $\begin{array}{l}\text { Mengemb } \\
\text { angkan } \\
\text { sikap } \\
\text { teliti, } \\
\text { jujur,sopa } \\
\text { n, } \\
\text { mengharg } \\
\text { ai } \\
\text { pendapat } \\
\text { orang } \\
\text { lain, } \\
\text { kemampu } \\
\text { an } \\
\text { berkomun } \\
\text { ikasi, } \\
\text { menerapk } \\
\text { an } \\
\text { kemampu } \\
\text { an } \\
\text { mengump } \\
\text { ulkan } \\
\text { informasi }\end{array}$ \\
\hline
\end{tabular}




\begin{tabular}{|c|c|c|}
\hline $\begin{array}{l}\text { Langkah } \\
\text { Pembelaj } \\
\text { aran }\end{array}$ & $\begin{array}{l}\text { Kegiatan } \\
\text { Belajar }\end{array}$ & $\begin{array}{l}\text { Kompete } \\
\text { nsi yang } \\
\text { Dikemba } \\
\text { ngkan }\end{array}$ \\
\hline & & $\begin{array}{l}\text { melalui } \\
\text { berbagai } \\
\text { cara yang } \\
\text { dipelajari, } \\
\text { mengemb } \\
\text { angkan } \\
\text { kebiasaan } \\
\text { belajar } \\
\text { dan } \\
\text { belajar } \\
\text { sepanjang } \\
\text { hayat. }\end{array}$ \\
\hline $\begin{array}{l}\text { Mengasosi } \\
\text { asikan/ } \\
\text { mengolah } \\
\text { informasi }\end{array}$ & $\begin{array}{l}\text { - mengolah } \\
\text { informasi } \\
\text { yang sudah } \\
\text { dikumpulkan } \\
\text { baik terbatas } \\
\text { dari hasil } \\
\text { kegiatan } \\
\text { mengumpulka } \\
\text { n/eksperimen } \\
\text { maupun hasil } \\
\text { dari kegiatan } \\
\text { mengamati } \\
\text { dan kegiatan } \\
\text { mengumpulka } \\
\text { n informasi. } \\
\text { - Pengolahan } \\
\text { informasi } \\
\text { yang } \\
\text { dikumpulkan } \\
\text { dari yang } \\
\text { bersifat } \\
\text { menambah } \\
\text { keluasan dan } \\
\text { kedalaman } \\
\text { sampai } \\
\text { kepada } \\
\text { pengolahan } \\
\text { informasi } \\
\text { yang bersifat } \\
\text { mencari solusi } \\
\text { dari berbagai } \\
\text { sumber yang } \\
\text { memiliki } \\
\text { pendapat yang }\end{array}$ & $\begin{array}{l}\text { Mengemb } \\
\text { angkan } \\
\text { sikap } \\
\text { jujur, } \\
\text { teliti, } \\
\text { disiplin, } \\
\text { taat } \\
\text { aturan, } \\
\text { kerja } \\
\text { keras, } \\
\text { kemampu } \\
\text { an } \\
\text { menerapk } \\
\text { an } \\
\text { prosedur } \\
\text { dan } \\
\text { kemampu } \\
\text { an } \\
\text { berpikir } \\
\text { induktif } \\
\text { serta } \\
\text { deduktif } \\
\text { dalam } \\
\text { menyimp } \\
\text { ulkan . }\end{array}$ \\
\hline
\end{tabular}

\begin{tabular}{|c|c|c|}
\hline $\begin{array}{l}\text { Langkah } \\
\text { Pembelaj } \\
\text { aran }\end{array}$ & $\begin{array}{l}\text { Kegiatan } \\
\text { Belajar }\end{array}$ & $\begin{array}{l}\text { Kompete } \\
\text { nsi yang } \\
\text { Dikemba } \\
\text { ngkan }\end{array}$ \\
\hline & $\begin{array}{l}\text { berbeda } \\
\text { sampai } \\
\text { kepada yang } \\
\text { bertentangan. }\end{array}$ & \\
\hline $\begin{array}{l}\text { Mengkom } \\
\text { unikasi- } \\
\text { kan }\end{array}$ & $\begin{array}{l}\text { Menyampaikan } \\
\text { hasil } \\
\text { pengamatan, } \\
\text { kesimpulan } \\
\text { berdasarkan } \\
\text { hasil analisis } \\
\text { secara lisan, } \\
\text { tertulis, atau } \\
\text { media lainnya }\end{array}$ & $\begin{array}{l}\text { Mengemb } \\
\text { angkan } \\
\text { sikap } \\
\text { jujur, } \\
\text { teliti, } \\
\text { toleransi, } \\
\text { kemampu } \\
\text { an } \\
\text { berpikir } \\
\text { sistematis, } \\
\text { mengungk } \\
\text { apkan } \\
\text { pendapat } \\
\text { dengan } \\
\text { singkat } \\
\text { dan jelas, } \\
\text { dan } \\
\text { mengemb } \\
\text { angkan } \\
\text { kemampu } \\
\text { an } \\
\text { berbahasa } \\
\text { yang baik } \\
\text { dan benar. }\end{array}$ \\
\hline
\end{tabular}

\section{Langkah-langkah Pembelajaran Bahasa Indonesia Menggunakan Pendekatan Saintifik.}

a) Melakukan Pengamatan

Pada langkah ini siswa mengamati penomena dengan panca indera (mendengar, melihat, membau, meraba, mengecap) dengan atau tanpa alat untuk menemukan masalah. Penomena ini dapat berupa kejadian / 
keadaan alam, peristiwa/situasi sosial/ interaksi/komunikasi verbal (bahasa).

b) Merumuskan Pertanyaan

Siswa merumuskan pertanyaan berangkat dari masalah yang diperoleh dari pengamatan. Pertanyaan yang dirumuskan jawabanya akan berupa pengetahuan factual, konseptual, dan metakognitif yang relevan dengan indicator pencapaian kompetensi.

c) Mencoba atau mengumpulkan data atau informasi

Siswa mengumpulkan informasi/data dengan satu atau lebih teknik yang sesuai, misalnya eksperiment, pengamatan, wawancara, survey dan membaca dokumen.

d) Mengasosiasi data atau informasi

Pada tahap ini siswa menggunakan informasi atau data yang sudah dikumpulkan untuk menjawab pertanyaan dan menarik simpulan.

e) Mengomunikasikan

Siswa menyampaikan jawaban atas pertanyaan secara lisan ataupun secara tertulis

f) Mencipta

Siswa mencipta/ menginovasi produk/ model, gagasan dengan pengetahuan yang telah diperoleh. Mencipta merupakan penerapan dari pengetahuan yang diperoleh, hasilnya berupa sesuatu yang berwujud produk atau karya maupun yang tidak berwujud seperti gagasan atau ide.

Pembelajaran berbasis teks dilakukan pada satuan teks dengan tujuan untuk melaksanakan berbagai tindakan komunikatif secara bermakana dengan menggunakan teks-teks yang bermanfaat dalam kehidupan peserta didik secara reseptif dan produktif, secara lisan maupun tulisan, diberbagai konteks yang relevan dengan kehidupan siswa dalam kegiatan mendengarkan, berbicara, membaca, dan menulis yang terintegrasi secara alami dalam kegiatan komunikatif yang bermakna.

\section{Pendekatan Saintifik dalam Kurikulum 2013}

\section{A. Definisi Pendekatan Saintifik}

Permendikbud No. 65 tahun 2013 tentang Standar Proses Pendidikan Dasar dan Menengah telah mengisyaratkan tentang perlunya proses pembelajaran yang dipandu dengan kaidah-kaidah pendekatan saintifik. Upaya penerapan dengan pendekatan saintifik proses pembelajaran ini sering disebut sebagai ciri khas yang menjadi kekuatan tersendiri dari keberadaan kurikulum 2013 yang menarik untuk dipelajari dan dielaborasikan lebih lanjut. 
Pendekatan saintifik merupakan metode yang bisa digunakan oleh para ilmuwan dalam menerapkan pengetahuan/ teori/ konsep. Pendekatan saintifik dapat dipahami sebagai pembelajaran yang terdiri atas kegiatan mengamati, menanya, merumuskan pertanyaan, mengumpulkan informasi dengan satu atau lebih teknik, menalar/ mengasosiasi, dan mengomunikasikan jawaban/simpulan (Kemntrian Pendidikan dan kebudayaan: 2016:29).

Berdasarkan Direktorat Pembinaan

Sekolah Menengah Pertama (2013:13) dijelaskan bahwadengan pendekatan saintifik dapat didefinisikan sebagai pembelajaranyang dirancang sedemikian rupa sehingga peserta didik secara aktif mengonstruksi konsep, hokum, dan prinsip melalui tahapan-tahapan mengamati (untuk mengidentifikasikan atau menemukan masalah), mengajukan pertanyaan atau merumuskan masalah, mengajukan atau merumuskan hipotesis, mengumpulkan data dengan berbagai teknik, menganalisis data dan menarik simpulan, dan mengomunikasikan konsep, hokum, dan prinsip yang ditentukan.

Sementara dalam Kementrian Pendidikan dan Kebudayaan (2014:23) dikemukakan bahwa pendekatan saintifik mengedepankan penalaran induktif dibandingkan dengan penalaran deduktif. Penalaran induktif memandang fenomena atau situasi spesifik untuk kemudian menarik simpulan secara menyeluruh.

\section{B. Prinsip-prinsip Pembelajaran} dengan Pendekatan Saintifik adalah sebagai berikut.

a) Berpusat pada peserta didik yaitu kegiatan aktif peserta didik secara fisik dan mental dalammembangun makna atau pemahaman suatu konsep, hokum dan prinsip.

b) Membentuk student's self concept yaitu membangun konsep berdasrkan pemahaman sendiri

c) Menghindari verbalisme.

d) Memberikan kesempatan kepada siswa untuk mengasimilasi dan mengakomodasi konsep, hokum dan prinsip.

e) Mendorong terjadinya peningkatan kecakapan berpikir siswa.

f) Meningkatkan motivasi belajar siswa.

g) Memberikan kesempatan kepada siswa untuk melatih kemampuan dalam komunikasi.

h) Memungkinkan adanya proses validasi terhadap konsep, hokum, dan prinsip yang dikonstruksikan siswa dalam struktur kognitifnya.

i) Melibatkan keterampilan proses sains dalam mengonstruksikan konsep, hokum, dan prinsip. 
j) Melibatkan proses kognitif yang potensial dalam merangsang perkembangan intelektual, khususnya keerampilan berpikir tingkat tinggi siswa (Kementerian Pendidikan dan kebudayaan: 2016: 30)

Banyak para ahli yang meyakini bahwa melalui pendekatan saintifik selalu menjadikan siswa lebih aktif dalam mengonstruksikan pengetahuan dan keterampilan, juga mendorong siswa untuk melakukan penyelidikan guna menemukan fakta dari fenomena atau kejadian.

Artinya dalam proses pembelajaran siswa dibelajrkan dan dibiasakan untuk menemukan kebenaran ilmiah. dalam penerapan pendekatan saintifik menuntut adanya perubahan setting dan bentuk pembelajaran tersendiri yang berbeda dengan pendekatan konvensional.

Pendekatan saintifik hendaknya diberikan sejak/mulai usia dini, dan dilakukan secara bertahap, karena pada saat ini anak mulai berpikir abstrak yang sangat sederhana kemudian berpikir sangat kompleks sesuai dengan kemampuan berpikirnya untuk dapat ditingkatkan kembali. Berdasarkan Permendikbud nomor 66 tahun 2013 bahwa penilaian pada pendekatan saitifik menggunakan penilaian nyata. Penilaian nyata yang dimaksudkan dalam proses pembelajaran guru mengumpulkan informasi tentang perkembangan belajar yang dilakukan siswa (Suwartono: 2014:36).

\section{C.Tujuan Pembelajaran}

a) Meningkatkan kemampuan intelektual, khususnya kemampuan berpikir tingkat tinggi siswa;

b) Membentuk kemampuan siswa dalam menyelesaikan suatu masalah secara sistematik;

c) Melatih siswa dalam mengomunikasikan ide, khususnya menulis karya ilmiah;

d) Memperoleh hasil belajar yang tinggi;

e) Mengembangkan karakter siswa

Dalam proses pembelajaran bahasa Indonesia dengan pendekatan saintifik, guru memiliki peran untuk merancang pembelajaran dengan baik, misalnya dalam merumuskanindikatordan menentukan tujuan pembelajaran, sampai dengan merancang instrument penilaian. Sedangkan peserta didik memiliki peran sebagai peserta didik dalam aktivitasnya harus selalu aktif dalam melakukan pengamatan, mengajukan pertanyaan secara kritis, mengumpulkan informasi, mengomunikasikan, dan mampu untuk menyajikan, serta mampu untuk menyimpulkan isi materi.

Proses pembelajaran melalui pendekatan saintifik, siswa lebih banyak untuk berdiskusi atau berkolaboratif 
dengan siswa lain, dengan maksud siswa secara mandiri mampu mengumpulkan, menanya, menafsirkan, mengomunikasikan, serta mampu menyajikan materi yang didiskusikan.

\section{PENUTUP}

\section{A. Simpulan}

Pembelajaran bahasa Indonesia berbasis teks maksudnyaguru mengenalkan teks dan tujuannya, serta fitur-fitur, membimbing peserta didik memproduksi teks melalui proses pemberian bantuan. Pembelajaran berbasis teks melibatkan proses dimana guru membantu peserta didik dalam memproduksi teks dan secara bertahap mengurangi bantuan supaya peserta didik mampu memproduksi teks secara mandiri.

Adapun teks dalam pembelajaran bahasa Indonesia meliputi (1) teks anekdot, (2) teks eksposisi, (3) teks laporan hasil observasi, (4) teks prosedur kompleks, (5) teks negosiasi, (6) teks cerita pendek, (7) teks pantun, (8) teks cerita ulang, (9) teks eksplanasi komplek, (10) teks film/darma, (11) teks cerita sejarah, (12) teks berita, (13) teks iklan, (14) teks editorial/opini, dan (15) teks novel.Melalaui teks-teks tersebut selain diajarkan ilmu kebahasaan juga diintegrasikan pendidikan karakter. Terlebih melalui pendekatan saintifik atau ilmi ah pembentukan karakter akan mudah terealisasikan. Dalam pendekatan saintifik, siswa diminta unntuk mengamati, menanya, mencoba, mengasosiasi, dan mengomunikasikan. Kegiatan-kegiatan tersebut dilakukan dengan integrasi pembentukan sikap, misal mengamati dengan tanggung jawab, menanya dengan santun, mencoba dengan jujur, dan mengasosiasi dan mengomunikasikan dengan proaktif. Sikap baik tersebut akan terus ditanamkan dalam setiap pembelajaran sehingga ketika peserta didik sudah terbiasa dengan sikap baikkebiasaan itu akan menjadi sifat, ketika peserta didik yang menjadi generasi penerus sudah menjadi pribadi yang baik tentu saja akan mengembalikan identitas bangsa menjadi bangsa yang bermartabat.

\section{B. Saran}

1) Guru bahasa Indonesia dapat menerapkan kurikulum 2013 dengan pendekatan saintifikmelalui tahapan mengamati, menanya, merumuskan pertanyaan, mengumpulkan informasi dengan satu atau lebih teknik, menalar/mengasosiasi, dan mengomunikasikan jawaban/simpulan.

2) Guru Bahasa Indonesia dapat melaksanakan berbagai tindakan komunikatif secara bermakana dengan menggunakan teks-teks 
yang bermanfaat dalam kehidupan

peserta didik secara reseptif dan

produktif, secara lisan maupun

tulisan;

3) Siswa dapat mengonstruksi teks secara mandiri

\section{Daftar Pustaka}

Emilia, E.2011. Pendekatan Genre-Based dalam Pengajaran Bahasa Inggris. Petunjuk untuk Guru. Bandung: Rizqi Press

Kementrian Pendidikan dan Kebudayaan Direktorat Jenderal Pendidikan Dasar dan Menengah. 2016. Panduan Pembelajaran untuk Sekolah Menengah.

Kemendikbud. 2014. Materi Pelatihan Implementasi Kurikulum 2013 Mata Pelajaran Bahasa Indonesia. Jakarta: BPSDMPKMP

Suwartono. 2014. Dasar-Dasar Metodologi Penelitian. Yogyakarta: Andi

Tri Priyatni Endah.2014. Desain Pembelajaran Bahasa Indonesia Dalam Kurikulum 2013. Cahaya Prima Sentosa: Jakarta.

Prastowo, Andi.2011. Panduan Kreatif Membuat Bahan Ajar Inovatif (menciptakan metode yang menarik dan menyenangkan) Yogyakarta: Diva Press

Permendikbud nomor 81A tahun 2013 Tentang Implementasi Kurikulum 2013 